\title{
Analysis of Implementation of DKI Jakarta's OK OCE Program Period of 2017-2018
}

\author{
$1^{\text {st }}$ Khikmatul Islah $^{1}, 2^{\text {nd }}$ Zakia $^{2}, 3^{\text {rd }}$ Istianah Setyaningsih ${ }^{3}$ \\ \{islahzone@gmail.com ${ }^{1}$, ashzalyzackia@gmail.com ${ }^{2}$, istianahsetyaningsih609@gmail.com ${ }^{3}$ \} \\ Faculty of Administrative Science, Institut Ilmu Sosial dan Manajemen Stiami ${ }^{1,3}$ \\ Faculty of Administrative Science, Universitas Indonesia ${ }^{2}$
}

\begin{abstract}
In the election of Governor and Deputy Governor of DKI Jakarta of 2017, OK OCE Program was introduced to the public. This program is carried out by Anies Baswedan and Sandiaga Uno. OK OCE program is an entrepreneurship-based program which will be centered in each sub-district of each region in Jakarta. In accordance with the program, OK OCE stands for One Sub-District One Center of Entrepreneurship. The program is motivated by the unemployment rate in Jakarta which is higher than the national unemployment rate with the concept of giving birth to 200,000 new entrepreneurs or businessmen. OK OCE Program has been implemented, including training for self-development. This implementation process is the study of this research, in terms of how effective the implementation of OK OCE program is. The long-term goal to be achieved by this research is to educate the public about the existence of OK OCE Program for them to participate actively in the program. The specific target to be achieved is to analyze the OK OCE Program implementation in DKI Jakarta. The method that will be used in this study is a qualitative descriptive research method. The data collection technique will be carried out by in-depth interviews.
\end{abstract}

Keywords: OK OCE, Entrepreneurship, Community Empowerment.

\section{Introduction}

Human empowerment is a top priority in development (Hidayat, 2017). The more individual empowerment increases, the more community empowerment as a collective increase. Increasing the ability of individuals and groups will lead to an increase in the general welfare of a region. The poverty alleviation program has become an important issue in the government's development program. The government's concern for overcoming unemployment and poverty is reflected in the Indonesian National Development Policy. This policy is reflected in the triple track development, i.e. pro-poor, pro-job, and pro-growth development programs (Sartika, 2019).

It seems that until now the challenges of poverty faced by Indonesia are still large, complex and even very complex. The government program that has been rolled out so far has not given significant results to poverty reduction especially in reducing the number of unemployed people in Indonesia both at the central and regional levels (Sisnita, 2017). As an example, in DKI Jakarta Province, based on the results of research the Central Statistics Agency, it shows that the unemployment rate in Jakarta is higher than the national unemployment rate. The unemployment rate in DKI Jakarta is $5.77 \%$, greater than the national 
unemployment rate of only 5.5\%. The BPS data even stated that the Jakarta Open Unemployment Rate (TPT) in August 2017 reached 7.14\%. (Source: http://sirusa.bps.go.id)

The high unemployment rate is the background for the birth of OK OCE Program carried out by Anies Baswedan and Sandiaga Uno in the election of the Governor of DKI Jakarta in 2017. OK OCE program stands for One Sub-District One Center of Entrepreneurship, which aims to reduce unemployment in Jakarta. Through this program, Anies Baswedan and Sandiaga Uno said that they would produce 200 thousand new entrepreneurs with the hope that unemployment in Jakarta would decrease and that more people would live independently without relying on others.

Table 1. Member of OK OCE in DKI Jakarta (10 November 2018)

\begin{tabular}{|l|l|l|}
\hline No. & Districts & Members \\
\hline 1. & Jakarta Barat & 9,450 \\
\hline 2. & Jakarta Timur & 9,357 \\
\hline 3. & Jakarta Selatan & 8,487 \\
\hline 4. & Jakarta Utara & 8,359 \\
\hline 5. & Jakarta Pusat & 7,346 \\
\hline 6. & Kabupaten Adm. Kep. Seribu $\quad$ (Source: https://okoce.me) & 1,512 \\
\hline
\end{tabular}

In connection with OK OCE program, Anies Baswedan and Sandiaga Uno must have a strategy in implementing OK OCE program in order to run according to expectations. One of the factors being conducted in this program is by empowering the community (Retno, 2019). For those who are unemployed, training will be given according to their choice of interests and talents, while those who have started a business will be given assistance. Based on that, the researcher intends to find out how effective OK OCE program is implementing in DKI Jakarta with the aim of providing benefits to the community.

\section{Literature Review}

The government is inseparable from the various complexities that are need great help and attention. In response to this question, the government issued policies that are used as a basis for government action in solving a problem (Rahadian, n.d.). This is similar with Anderson's opinion (2003: 6) which discusses public policy is "the action taken intentionally followed by an actor or series of actors in dealing with a problem or problem of concern". Policy is a step taken deliberately by an actor or a number of actors relating to existing or related problems. The stages of public policy according to Dunn (2003: 25) include the stage of preparing the agenda, the stage of policy formulation, the stage of policy adoption, the stage of policy implementation, and the stage of policy evaluation. The stage of implementing public policy is one of the most important activities and also the most difficult stage because at this stage various interests will be found (Pancari \& Budi, 2014).

OK OCE Program is also a government program and seeks to provide aid for its people to be more empowered and engaged. This program also involves communities. Various communities are embraced to be active and the community itself can be active as an assistant or as a participant to jointly realize the goal to solve the problem of unemployment.

All these goals will be achieved if the implementation of the program can run effectively. According to Edwards III (1980) there are four factors which are the main requirements for 
the success of the implementation process, these four factors function continuously and are related to each other to help and hinder policy implementation, so the ideal approach is to reflect this complexity by discussing all of these factors at once. These four factors include:

a. Communication.

b. Resources.

c. Disposition.

d. Bureaucratic structure.

\section{Research Metodology}

This study uses a post positivist approach. Based on research objectives, this type of research classified as descriptive research because it is research conducted in the context of making a picture of a particular situation or event. Based on data collection techniques, this study uses techniques qualitative data collection. Primary data collection in this study uses indepth interviews and observation techniques, where then the primary data will be combined with secondary data obtained through literature study.

\section{Discussion}

The implementation of OK OCE Program in DKI Jakarta has been in operation since the election of Anies Baswedan and Sandiaga Uno as the Governor and Deputy Governor. Various collaborations have also been carried out by DKI Jakarta Provincial Government for the success of the program. Cooperation agreement between the OK OCE Movement Association (PGO) and the DKI Provincial Government was carried out since Anies Baswedan took office, of which OK OCE has become the flagship program since it was a campaign promise that must be implemented and realized. The realization came into being since he was inaugurated in October 2017. The following months of November and December, PGO conducted the socialization. In January, OK OCE Centers have been established in 44 sub-districts, and in February, the assistants were in effect.

The assistant is provided by the Provincial Government, PGO provides input on who can be an assistant by including the terms or criteria which has come into force in the Governor Regulation. PGO provides consultations, curriculum, and materials to be implemented by the government since the budget and area are the affairs of the DKI Jakarta Provincial Government. The government is also close to the community and can invite the community.

Based on the results of the research, the level of effectiveness of its implementation can be seen from the following 4 issues:

\section{Communication}

The OK OCE program implemented in DKI Jakarta Province is a government cooperation program with the OK OCE Movement Association (PGO). This collaboration is regulated in Governor Instruction Number 152 of 2017 (Jakarta, 2017) concerning Establishment and Development of Entrepreneurship and Governor Regulation Number 102 of 2018 concerning Integrated Entrepreneurship Development (Pamungkas \& Yusuf, 2017). OK OCE is a brand that is used as an agreement between the Provincial Government and PGO for the success of 
the Integrated Entrepreneurship Program. The implementing agencies of the OK OCE Program consists of:

1. DKI Jakarta Provincial Government, which consists of the Economic Sector, Economic SKPD, and sub-districts;

2. OK OCE Movement Association as a provider of mobilizers and aid in activities based on the needs of the Provincial Government;

3. Private, and

4. Communities as users.

a. Communication between implementing agencies

Communication is well established, this can be seen from the form of coordination that has been established between PGO and the Provincial Government in providing training and the 7-step PAS (Certain to Succeed) Activities. This includes in the selection of assistants who will be assigned by the Provincial Government, with prior coordination with PGO. Communication between the government and the community is carried out by providing OK OCE Center services located in 44 sub-districts in each sub-district office in DKI Jakarta Province. In addition to communication related to the OK OCE program, public can access information from the OK OCE official website in regards to the implementation of the 7 PAS program.

b. Availability of Implementing Resources

The availability of implementing resources from DKI Jakarta Province is sufficient, where each OK OCE center in the sub-district has an assistant in charge of providing assistance from 7-step PAS to participants.

c. Attitude of Response of Policy implementers

The responsiveness of policy implementers is considered quite good, this can be seen from the continued use of the OK OCE brand in implementing policies, despite the official name of the program is integrated entrepreneurship program in accordance with DKI Governor Regulation 102/2018. This responsiveness is also related to the response given by the Provincial Government in determining the assistant with the criteria agreed upon with PGO. The good response from the implementers affected the success of the program, whereas of the end of 201843,000 participants had registered on the OK OCE website.

d. Implementing Organizational Structure

The implementing organization in the OK OCE program in the DKI Jakarta Provincial Government consists of 3 elements, i.e. the community as beneficiaries, mobilizers (PGO), private sectors and the Provincial Government of DKI Jakarta.

\section{Resources}

In order to facilitate the analysis of resource indicators, analysis is classified based on a series of entrepreneurial capacity building program (7 PAS) in the implementation of the OK OCE program (Wati \& Pamungkas, 2018), namely as follows:

\section{$\checkmark \quad$ Step 1: Registration}

The human resources of implementing the program at this stage involve Village Heads who play the role of helping to accelerate the implementation of the program by facilitating the registration of community groups through the application of Integrated Entrepreneurship 
Development (PKT). In addition, the Village Heads are also responsible for providing information and disseminating information to citizens regarding the benefits of implementing the CCP through an entrepreneurial capacity building program. The community/target groups that have been registered as program participants are then required to take part in an interview by the DKI Jakarta Provincial Manpower Office. The decision regarding the qualification of the interview result will further be determined by the Decree of the Head of Regional Apparatus as the executor of the CCP. In addition to these parties, there are also sub-district facilitators who have the function to help smooth the implementation of the program in which the assistants are selected and chosen according to the predetermined criteria.

Supporting resources at this stage are technology-based registration systems called PKT applications, which are managed directly by the DKI Jakarta Provincial Manpower Office and regional apparatus in the field of communication and informatics in accordance with the developed SOP for governance of the PKT application.

\section{$\checkmark \quad$ Step 2: Training}

Training of human resources is related SKPD/UKPD apparatus in DKI Jakarta Province and communities of self-supporting mobilizers in the sub-district office. Special soft skills are provided by the KUKM and Trade Office, while hard skills are provided by other related offices such as the Office of Industry, Maritime and Fisheries Office, Manpower Office, Culture and Tourism Office, Women's Empowerment and Social Service Office. Sub-district facilitators are also involved at this stage. In conducting training, the regional apparatus as the executor of the PKT can involve information sources or experts who must meet the criteria.

Other supporting resources are curriculum or training materials provided to the community/target groups of the program. In order for the training stage to run effectively, the entrepreneurship training level is divided into two types, namely: (1) Basic level training, which is aimed at the target group of job seekers and novice entrepreneurs who want to start their business. For this level, the training materials that will be provided include motivation and entrepreneurship; business ideas and concepts; basic financial planning, management and reporting through the application. (2) Advanced level training, which is aimed at upscale entrepreneurs who want to develop their business. The training material given at this level is entrepreneurial development orientation; and increasing the ability of business specialization and business management.

$\checkmark$ Step 3: Assistance

In business assistance, the resources involved are PKT implementing regional apparatus that can be assisted by:

1. Other Individual Service Providers (PJLP)

2. Business Assistant

Supporting resources in this stage are entrepreneurship clinics, which is a creative coworking space with the function as guidance, communication, information, interaction, and business promotion center. The provision of entrepreneurship clinic is the responsibility of regional apparatus in the field of cooperatives, small and medium business as well as trade (at least 5 urban areas and 1 district) for PKT Participants. In addition, OK OCE Centers have also been provided in 44 sub-districts to offer business assistance.

$\checkmark \quad$ Step 4: Licensing

In the framework of accelerating and prioritizing the process of entrepreneurship documents management for PKT participants, human resources that have been prepared to facilitate the licensing and non-licensing document are conducted collectively by regional 
apparatus of implementing PKT in coordination with regional apparatus in the field of investment and PTSP. While the provision of supporting resources is OK OCE Global Office, which is a virtual office run by the mobilizer to assist in facilitating domicile rent service, licensing and legality in accordance with the needs of the members/program participants.

$\checkmark \quad$ Step 5: Marketing

Human resources involved at this stage are all PKT implementing apparatus such as the KUKM Office, Industry Office, Maritime and Fisheries Office, Manpower Office, Culture and Tourism Office, Women's Empowerment and Child Protection Office, Social Office. The PKT implementing regional apparatus is responsible for facilitating marketing activities at least once a month through bazaar and other activities. Whereas marketing conducted jointly by all PKT implementing regions is carried out at least every 3 months through entrepreneurial exhibitions either locally, nationally or internationally under the coordination of the Assistant Regional Secretary for Economic and Financial Affairs. In addition to coordinate these marketing activities, the Assistant Regional Secretary for Economics and Finance is also responsible for coordinating the formation of networks and markets along with each regional apparatus so that the DKI Jakarta Provincial Government can always prioritize the use of products from PKT participants for every work activity carried out from the process of procurement of goods/services in accordance with applicable rules.

Other supporting resources in addition to the joint market policy are the provision of marketing information systems managed by regional communication and informatics apparatus to integrate information systems for the implementation of PKT into the digital entrepreneurial ecosystem. In addition, marketing products/services for program members will also be assisted by the mechanism of Retailers, Franchises, Resellers, Development Location/ Temporary Location, Online Stores, Bazaars/Exhibitions and Exports.

$\checkmark \quad$ Step 6: Financial Reporting

Participants who have obtained licensing documents and marketing facilities are then entitled to receive financial reporting training. In this stage, the community/target group of the program is trained to calculate turnover, profit and prepare financial reporting according to the standard accounting, which will be required as a supplementary condition for filing capital to other banks/capital institutions.

Preparation of business financial reporting in this program is application-based, facilitated by regional apparatus of implementing PKT. Some of the human resources involved in managing this application are, the PKT implementing regional apparatus that is authorized to make Standard Operational Procedures, and regional apparatus in the field of communication and informatics that are responsible for building, developing and integrating the application system. Regional apparatus in the field of communication and informatics may cooperate with information technology developers, such as Zahir who currently assists in the preparation of business financial reporting for the community/program target groups.

\section{$\checkmark \quad$ Step 7: Capital}

At this stage, the resources involved are regional apparatus in cooperatives, small and medium enterprises as well as trade that are responsible for facilitating easy access to capital for the community/target groups that have participated in the entire series of entrepreneurial capacity building programs. In order to support its function, cooperation with banking institutions or financial services institutions are implemented, such as the one currently in cooperation is Bank DKI. 
In addition to human resources, supporting resources such as facilities and infrastructure for PKT participants to develop their business can be provided through optimizing the use of facilities and infrastructure that they already have, by providing assistance for facilities and infrastructure such as work tools and other supporting facilities by the mechanism of grants in the form of goods which the value is regulated in the Decree of the Governor.

Table 2. Status of 7 PAS in DKI Jakarta (10 November 2018)

\begin{tabular}{|l|l|l|l|l|l|l|l|l|l|}
\hline \multicolumn{10}{|c|}{ Top 8 - status7pas / Status of 7 PAS } \\
\hline No. & Districts & Step 1 & Step 2 & Step 3 & Step 4 & Step 5 & Step 6 & Step 7 & \\
\hline 1. & Jakarta Barat & 241 & 55 & 9,237 & 5 & 16 & & 67 & 9,621 \\
\hline 2. & Jakarta Timur & 88 & & 9,287 & 46 & 36 & 13 & 61 & 9,531 \\
\hline 3. & Jakarta Selatan & 96 & & 8,764 & 10 & 29 & 7 & 44 & 8,950 \\
\hline 4. & Jakarta Utara & 272 & & 8,023 & 15 & 10 & 37 & 48 & 8,405 \\
\hline 5. & Jakarta Pusat & 161 & 61 & 7,132 & & & & & 7,354 \\
\hline 6. & Kep. Seribu & 1,811 & \multicolumn{7}{|c|}{ (Source: https://okoce.me) } \\
\hline
\end{tabular}

\section{Disposition}

In its implementation, capital is not a reference to the success of the program, because OK OCE DKI Jakarta runs through five materials obtained during training, namely mental changes or mindset, business projections, business selection and management. Prior to OK OCE there were several entrepreneurial programs, one of which was revolving fund where participants came, educated then received funds. But in reality, the funds obtained are not necessarily used for entrepreneurship. Therefore, in the first OK OCE training, participants were given material on mental changes and mindset. The training was conducted by using coaching method. Mental and mindset were trained first. Therefore, licensing is currently being used, because hitherto the benchmark success of OK OCE has only been seen from capital loans.

\section{Bureaucratic structure}

In the bureaucratic structure, many parties are involved in the implementation of OK OCE program. Based on the Regulation of the Governor of DKI Jakarta Province Number 102 of 2018, several related bureaucracies are: (a) Regional Secretary, (b) Mayor of DKI Jakarta Province, (c) Regent of Kepulauan Seribu, and (d) Head of Regional Equipment.

\section{Conclusion}

Basically, the OK OCE Program has been implemented by the Provincial Government of DKI Jakarta in accordance with the campaign promise of the elected Governor and Deputy Governor, Anies Baswedan and Sandiaga Uno. If viewed from the benchmark of achieving 200 thousand entrepreneurs, in accordance with the applicants of training program between the periods of 2017-2018, the target has reached 40 thousand participants. However, if viewed from 7 PAS where licensing step is present, the aforementioned target of 40 thousand participants of business licenses has not yet been reached. This is due to the need for licensing 
process. Subsequently, this program can continue to be implemented in accordance with applicable regulations, and as for licensing, it is expected that the DKI Jakarta Provincial Government will provide convenience for OK OCE participants so that the target of achieving 200 thousand entrepreneurs within 5 years can be achieved.

\section{Thank-You Note}

The researchers would like to thank:

1. Ministry of Research, Technology and Higher Education of the Republic of Indonesia.

2. Institute of Social and Management Sciences of STIAMI.

3. LPPM Institute of Social and Management Sciences of STIAMI.

4. All parties who have assisted in completing this research.

\section{References}

[1]. Hidayat, C. W. (2017). Model Pengembangan dan Pemberdayaan Masyarakat untuk Mewujudkan Ketahanan Ekonomi. Jurnal Organisasi Dan Manajemen, 8(2), 649-653.

[2]. Jakarta, G. P. D. Peraturan Gubernur 152 tahun 2017, Pub. L. No. 152/2017 (2017). Indonesia.

[3]. Pamungkas, B., \& Yusuf, M. (2017). One Kecamatan One Center for Entrepreneurship ( OK-OCE ) dalam Ekosistem Kewirausahaan Kota Jakarta : Kerangka Kebijakan dan Kemitraan Stakeholders Bani Pamungkas.

[4]. Pancari, A., \& Budi, K. (2014). Analisis Implementasi Undang-Undang Keterbukaan Informasi Publik oleh Dinas Pendidikan DKI Jakarta, (2014).

[5]. Rahadian, A. P. (n.d.). Analisis Implementasi Kebijakan Tentang Keterbukaan Informasi Publik Studi Kasus Pada Kementerian Pertanian, (1994), 1-17.

[6]. Retno, S. I. (2019). Implementasi Program Ok Oce Bagi Kesejahteraan Keluarga (Studi Kasus OK OCE Kecamatan Kembangan, Jakarta Barat). Uin Syarif Hidayatullah.

[7]. Sartika, I. (2019). Quo Vadis "Ok Oce": Collaborative Governance Sebuah Solusi. Jurnal Ilmu Pemerintahan, 54. Retrieved from http://eprints.ipdn.ac.id/id/eprint/2762

[8]. Sisnita, A. (2017). Analisis Faktor-Faktor Yang Mempengaruhi Tingkat Pengangguran Terbuka Di Provinsi Lampung (Periode 2009-2015). Journal of Chemical Information and Modeling, 53(9). https://doi.org/10.1017/CBO9781107415324.004

[9]. Wati, S., \& Pamungkas, B. (2018). Collaborative Governance Dalam Ekosistem Kewirausahaan: Studi Kasus Implementasi OK OCE di Kota Jakarta. In Konferensi Nasional Ilmu Administrasi 2.0 (pp. 221-227). Bandung: KNIA 2018.

[10]. http://sirusa.bps.go.id/index.php?r=indikator/view\&id=44.

[11]. www.okoce.me. 